Vol. 3, No. 1, 2020

\author{
T. Garbacz ${ }^{1}$, L. Dulebova ${ }^{2}$ \\ ${ }^{1}$ Lublin University of Technology, Lublin, Poland, \\ ${ }^{2}$ Technical University of Kosice, Kosice, Slovakia \\ t.garbacz@pollub.pl
}

\title{
PROCESSING OF SELECTED PROPERTIES OF EXTRUDED RECYCLED PLASTICS
}

https://doi.org/

The aim of the study is to analyze the physical processing properties and morphology of recycled plastics. The scope of work includes conducting the processing of primary PVC and recycled PVC and testing mechanical properties such as: tensile strength, stress, elongation and impact resistance, hardness. The scope of work also includes shrinkage testing of primary compacts and structural investigation of the morphology of materials. The technology for producing the recycled composition is based on the extrusion and compression technology of the compositions obtained. The research on the structure of manufactured materials, melt flow index MFI, and macroscopic structure are presented.

Key words: PVC, blowing agent, cellular processing, recykled, properties, structure.

\section{Introduction}

Modification of polymeric materials is intended to give the products specific properties or in the case of hard to recycle materials, facilitate their processing. The modification process involves changing the technological conditions of the manufacturing process, the processing tools as well as the addition of auxiliary materials such as fillers, plasticizers and stabilizers. Aids can be divided into two main groups: processing and functional. Group of processing agents are processing stabilizers and processing modifiers. The functional agents include properties stabilizers and property modificators.

Functional modifiers are primarily property stabilizers that prevent the behavior of the material during its further use. The properties stabilizers include, among others, anti-aging agents that prevent the release of harmful disintegrants, metal deactivators, anti-aging electric compositess and hydrodesistant stabilizers, prevent water effect.

A large separate group is properties modifiers. They make it possible to change the optical, mechanical, surface, flammability properties.

Modifiers include also porous and microporous blowing agents (porophors). Their main ingredient is gas, which, under appropriate conditions of the process, expands, resulting in porosity. The obtained product changes its structure from solid to porous. Mold the material so that the separated gas can be cooled down and concentrate the microporous material. This modifier affects many properties such as density, hardness, elasticity, tensile strength, stiffness [1-6].

\section{Characteristic of cellular plastics}

A growing interest in cellular plastics and the methods of their manufacture has led to the development of a new processing method of cellular extrusion and injection molding. Cellular extrusion and injection molding of thermoplastics has in recent years been one of the faster developing methods of polymer processing. The method is mainly used in the manufacture of various cellular profiles of reduced density, without hollows on the surface, which show minimal processing shrinkage, at the same time retaining properties similar to those of products extruded using the conventional method. Constant development of cellular extrusion in terms of the process itself and the design of the component elements of extrusion lines creates new research possibilities [2, 3, 5-7].

Properly selected processing conditions make it possible to manufacture products with new, modified physical and technological properties. The new products are characterized, among others, by reduced weight, improved damping and insulation properties and the possibility of utilization after use, retaining at the same time physical and technological 
properties similar or identical to those of cellular products. To obtain cellular structure, the properties of an products are modified by using an appropriate type of polymer or by incorporating blowing agents (porophors) into the polymer.
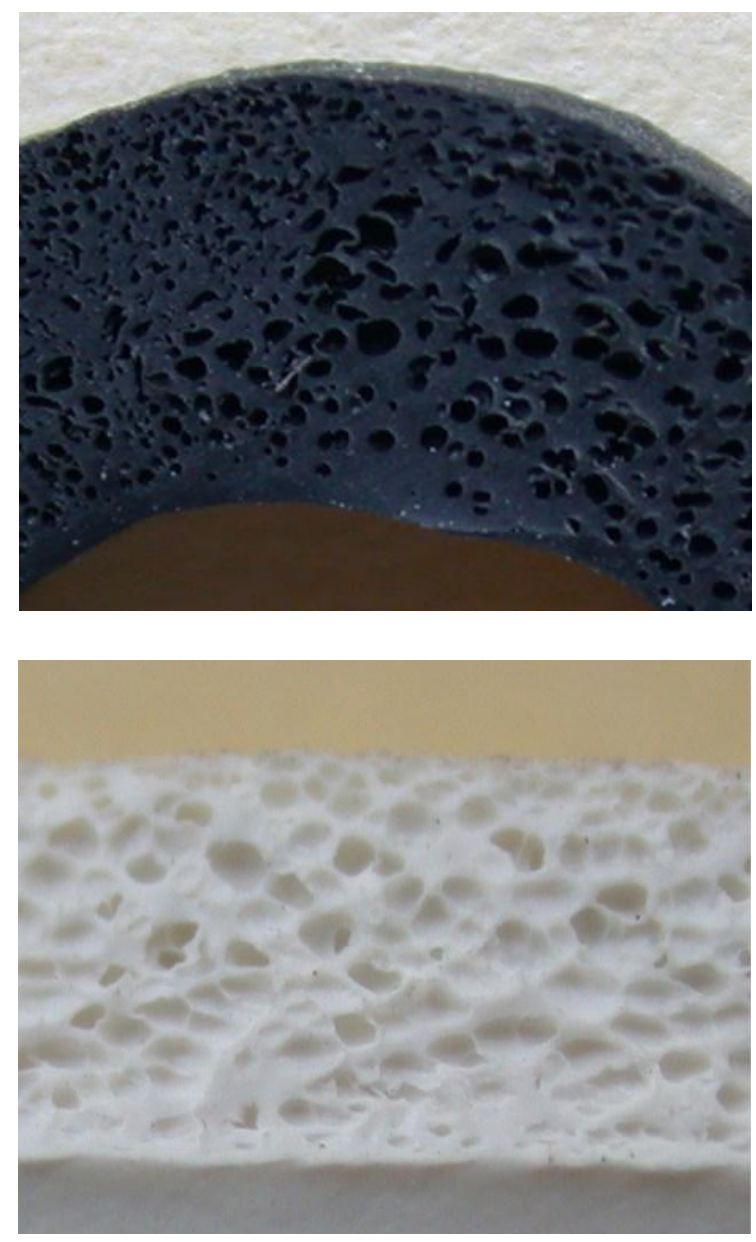

Fig. 1. Example of cellular products made during extrusion process [photos of the author]

Cellular extrusion consists in introducing into a polymer plastic a blowing agent, which, under appropriate pressure and temperature conditions, decomposes, emitting gas. This gas dissolves in the polymer. Next, after the pressure drops, the gas begins to evolve from the polymer producing cellular structure, which has to be solidified by cooling the cellular product $[2,3,7,8,9]$. A blowing agent (a porophor) can be gaseous, solid or liquid. Gases and liquids are introduced into the input polymer under appropriate conditions - under pressure, using special devices which deliver them to the feed section of the plasticating system. Solids, on the other hand, as well as some liquids, are incorporated into the polymer already during its production. To obtain cellular structure, the properties of an extrudate are modified by using an appropriate type of polymer or by incorporating blowing agents into the polymer. The obtained extrudate may have an entirely solid or an entirely cellular structure; it may be cellular across its thickness or have a cellular core with a solid outer skin $[4,7,8,10-12]$.

Blowing agents used in the extrusion process can be divided into physical and chemical, however this classification is traditional and not exactly accurate.

Physical blowing agents (physical porophors) comprise substances which do not change their chemical structure during the extrusion process; they only change their state of aggregation. Chemical blowing agents (chemical porophors) act similarly as physical porophors, yet gaseous products generated as a result of their decomposition and causing the cellular extrusion effect, remain inside the plastic material. Inert gases and low-boiling liquids are introduced under pressure by means of special dispensing devices directly into the feeding zone of the plasticizing unit of the extrusion machines during the extrusion process. When in the proper temperature the process of gas emission is started, numerous microspheres which are then generated dissolve in the ambient plastic material due to the operation of pressure and surface development. Theemerging cells may be filled with air or with any other gases, for instance $\mathrm{CO}_{2}$ andN $\mathrm{N}_{2}$, yet later they are replaced by air as a result of diffusion $[4,5,8$, $13,14,15,16]$.

\section{The Purpose of Study}

Research on cellular extrusion conducted by the author focuses, inter alia, on the production of products from cellular plastics, which results in reduced costs of purchasing plastics, costs of energy required by the process and transport costs, etc. Research on the cellular extrusion of thermoplastics focuses on the process where product properties are modified by changing the conditions of extrusion and the properties of the processing line structural elements. The extrusion of products with the use of blowing agents results in new, modified physical and technological properties of cellular products.

The aim of the study is to analyze the physical processing properties and morphology of recycled plastics. The scope of work includes conducting the processing of primary PVC and recycled PVC. The scope of work also includes shrinkage testing of 


\section{T. Garbacz, L. Dulebova}

primary compacts and structural investigation of the morphology of materials.

\section{Materials and Methods}

In the studies polyvinyl chloride (PVC) manufactured by Alfa sp.z.o.o. (Poland), Alfavinyl GFM/4-31, was used in the study on cellular extrusion process. This plastic has density of 1230 $\mathrm{kg} / \mathrm{m} 3$ and hardness of $80 \mathrm{Sh}^{\circ}$ A. Polyvinyl chloride was modified by auxiliary agents in the form of polyvinyl chloride concentrates PVC has found its way into a wide variety of applications, which can be attributed to its unique ability to be formulated into a multitude of compounds that can be converted to a large diversity of useful products.Consequelly, PVC foams are distingnished from most other types of plastic foams by a broad range of unique characteristics.

In the experiments described in the present paper, one type of blowing agents were used. Chemical blowing agents are modifiers that generate gases through chemical reactions at elevated temperatures and the decomposition of organic or non-organic bonds, in effect producing a cellular structure due to affinity for polymer. In the experiments, various types of chemical blowing agents were used: Expancel 950 MB80 manufactured by Akzo Nobel.

Expancel $950 \mathrm{MB} 80$ is a blowing agent that has the form of spherical thermoplastic polymer capsules (microspheres) that contain a hydrocarbon gas. This is an endothermic blowing agent. Expancel microspheres do not bond because the capsules retain their blocking properties, which prevents release of the constrained gas. Expancel $950 \mathrm{MB} 80$ is a mixture that contains $65 \%$ microspheres in the copolymerof ethylene and vinyl acetate (EVA). The decomposition products of the applied blowing agents mainly include carbon dioxide $\mathrm{CO}_{2}$, a small amount of water $\mathrm{H}_{2} \mathrm{O}$ and nitrogen $\mathrm{N}_{2}$.

The polymer processing was carried out with the use of a single-screw extruder, type $\mathrm{W}-25$ with the screw diameter of $\mathrm{D}=25 \mathrm{~mm}$. The plasticizing unit was equipped with four heating zones. The process line was composed of the extrusion coating head, vacuum calibrator, the cooling bath and the remaining process line components.

The extrusion process was conducted at the following parameters: rational speed of the screw $1 \mathrm{~s}^{-}$ 1 , temperature of heating zones of the plasticating system respectively $120,130,140,150{ }^{\circ} \mathrm{C}$, temperature of the extruder head $145{ }^{\circ} \mathrm{C}$.

The process of grinding previously extruded samples was carried out on the Xiecheng XC-GP230 mill. It is a mill specially designed for grinding plastics materials with a capacity of 4 [kW].

The process of secondary extrusion of shredded PVC was carried out on the EHP $2 \times 20$ Sline twin screw extruder, the manufacturer of which is Zamak Mercator.

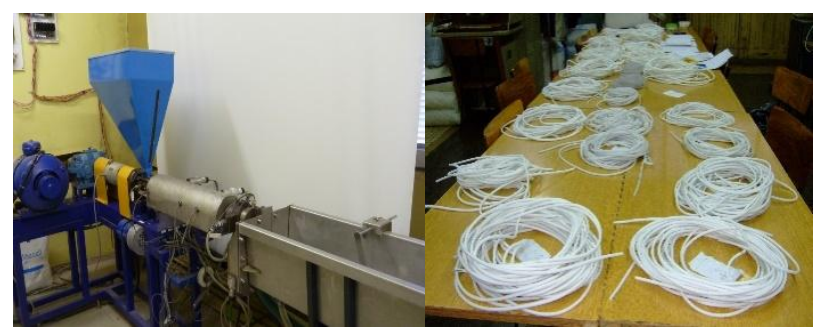

Fig. 2. View of technological line section for cellular extrusion process and made PVC products, example

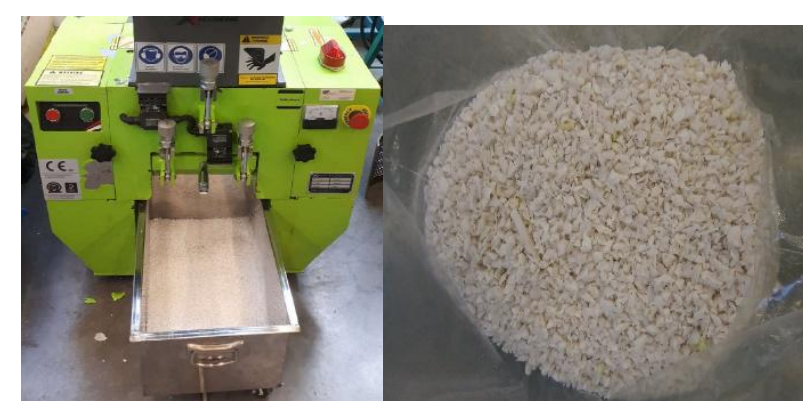

Fig. 3. Mill for recycling, Xiecheng XC-GP230 and recycled $P V C$

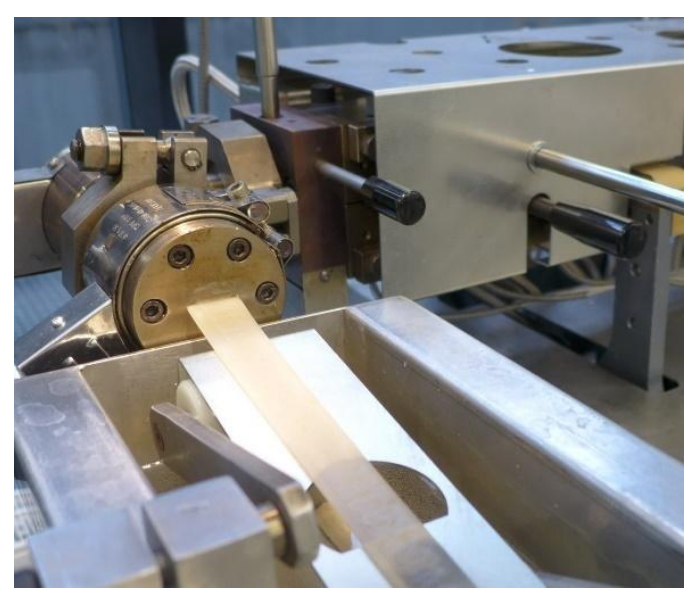

Fig. 4. View of technological line section for recycled plastics

The extrusion line consists of the following elements: co-rotating extruder EHP 2x20 Sline, single- 
screw volumetric feeder, twin-screw volumetric feeder, extruder head, cooling bath, digital line control system. The temperature of individual cylinder and charging areas is regulated by a water cooling system having its own water jacket. The process was carried out at a load of the drive system equal to $17 \%$ with a screw speed of $47 \mathrm{rpm}$. The secondary extrusion process is presented in Figure 4.

Based on the adopted research program, the polymeric material for polymer processing molding modifed in such a way that the blowing agents were fed into it during the mechanical mixing process. Polymers were modified by introducing blowing agents into them in the Laboratory of the Department of Technologies and Materiale of Technical University of Kosice. The mass of the individual components of the modified polymers, i.e., the contents of polymer and blowing agents, were measured with a WTE-2000 laboratory balance reading to $0.1 \mathrm{~g}$.

The blowing agents used in the polymer processing were fed into the polymers being processed in the following quantities: $0.5 \%, 1.0 \%$ and $2.0 \%$ by mass $(\mathrm{w} / \mathrm{w})$. In order to obtain high process efficiency for the above blowing agents, the processing temperature range was $170-210{ }^{\circ} \mathrm{C}$.

They are usually fed into the plasticizing unit using gravimetric or volumetric feeders. The polymer and blowing agent mixture then undergoes processing in the plasticizing unit and forming. In order to produce a favourable structure with small cells, the product should be cooled and solidified as quickly as possible.

\section{Results and Discussion}

The specimens of of the recycled plastics parts were then examined in structural properties in compliance with relevant recommendations and norms.

The Melt Flow Index (MFI) is a measure of the ease of flow of the melt of a thermoplasticpolymer. It is defined as the mass of polymer, in grams, flowing in ten minutes through a capillary of a specific diameter and length by a pressure applied via prescribed alternative gravimetric weights for alternative prescribed temperatures. Polymer processors usually correlate the value of MFI with the polymer grade that they have to choose for different processes, and most often this value is not accompanied by the units, because it is taken for granted to be $\mathrm{g} / 10 \mathrm{~min}$. Similarly, the test conditions of MFI measurement is normally expressed in kilograms rather than any other units. The method is described in the similar standards ASTM D1238 and ISO 1133.

MFI tests were carried out on the test stand equipped with a Ceast weight plastometer type 6542.00 with additional equipment and a laboratory balance. The appearance of the weight plastometer used for the tests is shown in Figure 5.

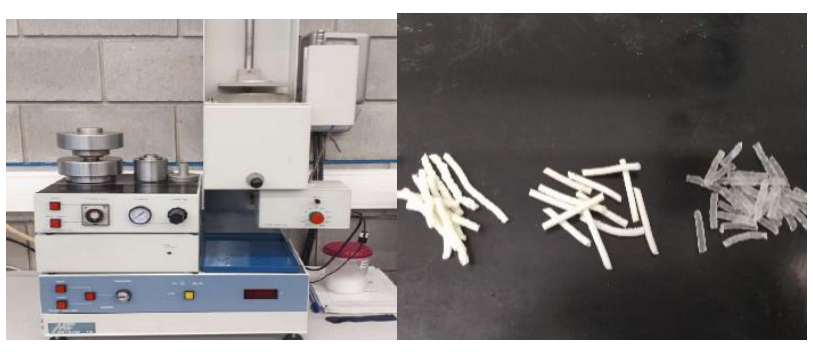

Fig. 5. Weight plasticizer (Ceast 6542.00) used for recycled plastics testing Extrudes during the MFI test in a plastomer, example

The result of the measurements carried out was the receipt of the MFI mass flow rate value for a poly (vinyl chloride) extrudate modified with a blowing agent. The range of obtained readings is from $2.27 \mathrm{~g} / 10 \mathrm{~min}$ at $0 \%$ mass content of the blowing agent to $4.55 \mathrm{~g} / 10 \mathrm{~min}$ at $1.5 \%$ mass content of the blowing agent. For the MFI secondary tape test, results were found in the range of $0.64 \mathrm{~g} /$ $10 \mathrm{~min}$ at $0 \%$ mass content of the blowing agent to $1.70 \mathrm{~g} / 10 \mathrm{~min}$ at $1.0 \%$ mass content of the blowing agentin recycled material.

\section{Table 1}

Test results of the MFI for PVC with Expancel blowing agent and recycled PVC; temperature: 155 ${ }^{0} \mathrm{C}$, load: $10.00 \mathrm{~kg}$

\begin{tabular}{|c|c|c|c|}
\hline \multirow{2}{*}{ Materials } & \multirow{2}{*}{$\begin{array}{c}\text { Contents of } \\
\text { blowing agent } \\
{[\%]}\end{array}$} & \multicolumn{2}{|c|}{$\begin{array}{l}\text { Average value MFI (155, } \\
10 \mathrm{~kg})[\mathrm{g} / 10 \mathrm{~min}]\end{array}$} \\
\hline & & $\begin{array}{c}\text { Primary } \\
\text { PVC }\end{array}$ & $\begin{array}{l}\text { Recycled } \\
\text { PVC }\end{array}$ \\
\hline \multirow{12}{*}{$\begin{array}{c}\mathrm{PVC}+ \\
\text { Expancel }\end{array}$} & 0 & 2,27 & 0,68 \\
\hline & 0,5 & 2,63 & 1,1 \\
\hline & 1,0 & 3,51 & 1,7 \\
\hline & 2,0 & 4,48 & 1,32 \\
\hline & 0 & 2,27 & 0,74 \\
\hline & 0,5 & 2,67 & 1,2 \\
\hline & 1,0 & 3,23 & 1,67 \\
\hline & 2,0 & 4,55 & 1,36 \\
\hline & 0 & 2,27 & 0,64 \\
\hline & 0,5 & 2,7 & 1,55 \\
\hline & 1,0 & 3,43 & 1,63 \\
\hline & 2,0 & 4,51 & 1,44 \\
\hline
\end{tabular}




\section{T. Garbacz, L. Dulebova}

The value of average values for individual materials with an indication of the content of the blowing agent was: $0.68 ; 1.28 ; 1.67 ; 1.37$. The relationship of these values is presented in the chart below.

The investigation and analysis of the porous structure of the produced parts were conducted using an confocal microscope, type Nikon ECLIPSE LV100ND and copyright position of image analysis of porous structure and the author's stand for porous structure image analysis. Observation of specimens structure and its recording was made in reflected light with suitable magnification.

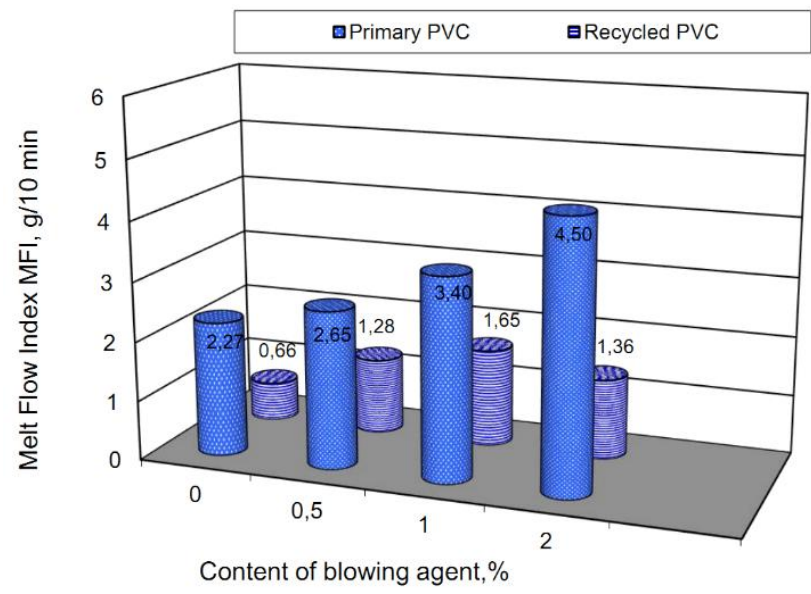

Fig. 6. Block diagrams illustrating the dependence of MFI on the blowing agent type and its content in primary and recycled $P V C$

The porous structure image analysis is used to determine geometric characteristics of pores based on the images of porous structure taken. The images are taken using an optical camera with an electronic amplifying system and then analyzed on a computer stand eq The blowing agent was dosed in $0.5-2.0 \%$ by weight, so as to produce extrudate with a solid surfaceand a cellular core.The shape and outside dimensions of the product agree with shape and dimensions of solid products made of the tested PVC. The macroscopic structure of the produced cellular tapes was examined at the stand for polymer cellular structure image analysis. The stand comprised a metallographic, optical image recording devices and a computer equipped with specialist software. The examples of the cellular structure injected parts are shown in Figures from 8 to 10. The morphology shows are porous in whole cross section area. There is no solid outer layer visible, as in the case of injection molded samples. Obtained pores have different size and shape. The closer to the core the solid outer layer is, the more the pore size increases (Fig. 7).

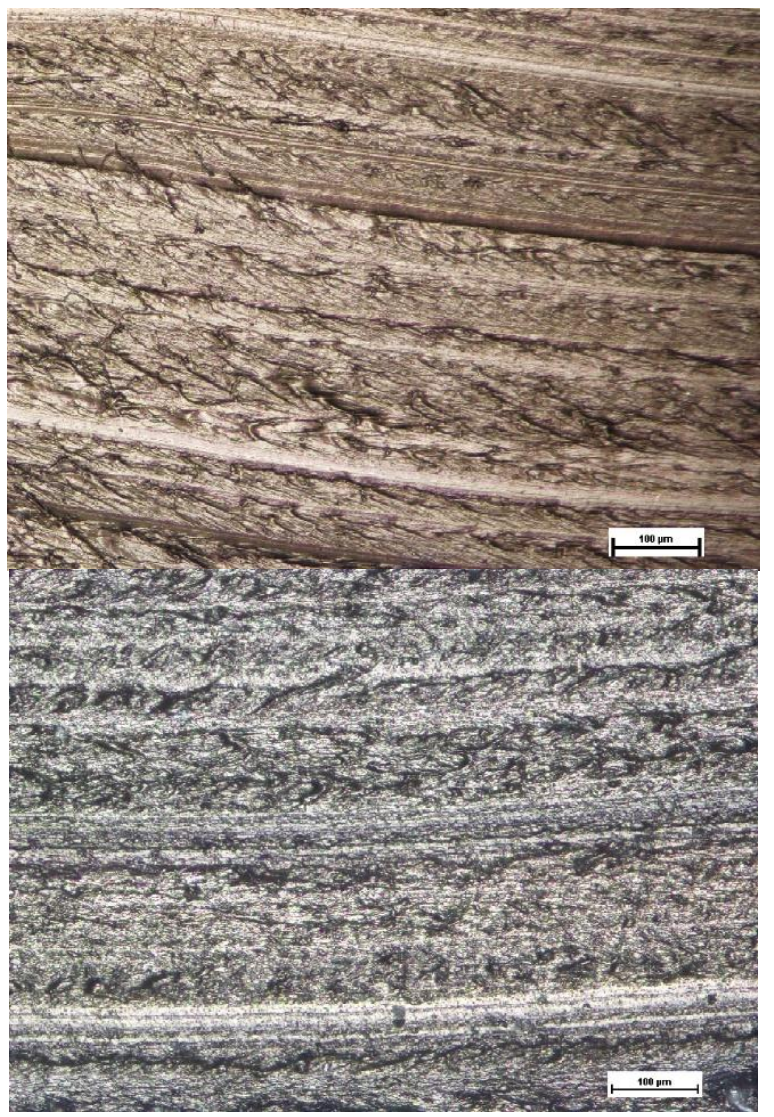

Fig. 7. Fragment of the cross section of the solid PVC and solid recycled $P V C$

Microscopic studies show the effect of secondary extrusion on the structure of porous poly (vinyl chloride) depending on the amount of blowing agent added, which was added in primary extrusion in the amounts: $0 \%, 0.5 \%, 1.0 \%$ and $2.0 \%$ by mass in relation to the weight of the processed material. Based on the obtained microscopic images, we can observe that after re-extrusion of porous PVC, pores still occurin the structure of the material, but their size has decreased and the quantity has decreased to such an extent that the extrudate no longer has a porous structure. The change in the number of pores and their surface quantity in the cross section of the molded parts can also depend on cooling intensity. Fast cooling hampers the occurrence and growth of the pores, especially of those located closer to the surface layer (Figs. 8, 9). In the case of the porous parts produced using the 


\section{Processing of selected properties of extruded recycled plastics}

blowing agent with the endothermic decomposition characteristics, the gas release in the course of processing comes to an end once the energy supply is stopped. The obtained porous structure is uniform; the pores have a spherical or quasi spherical shape. The pores have similar sizes, irrespective of their location in the product.
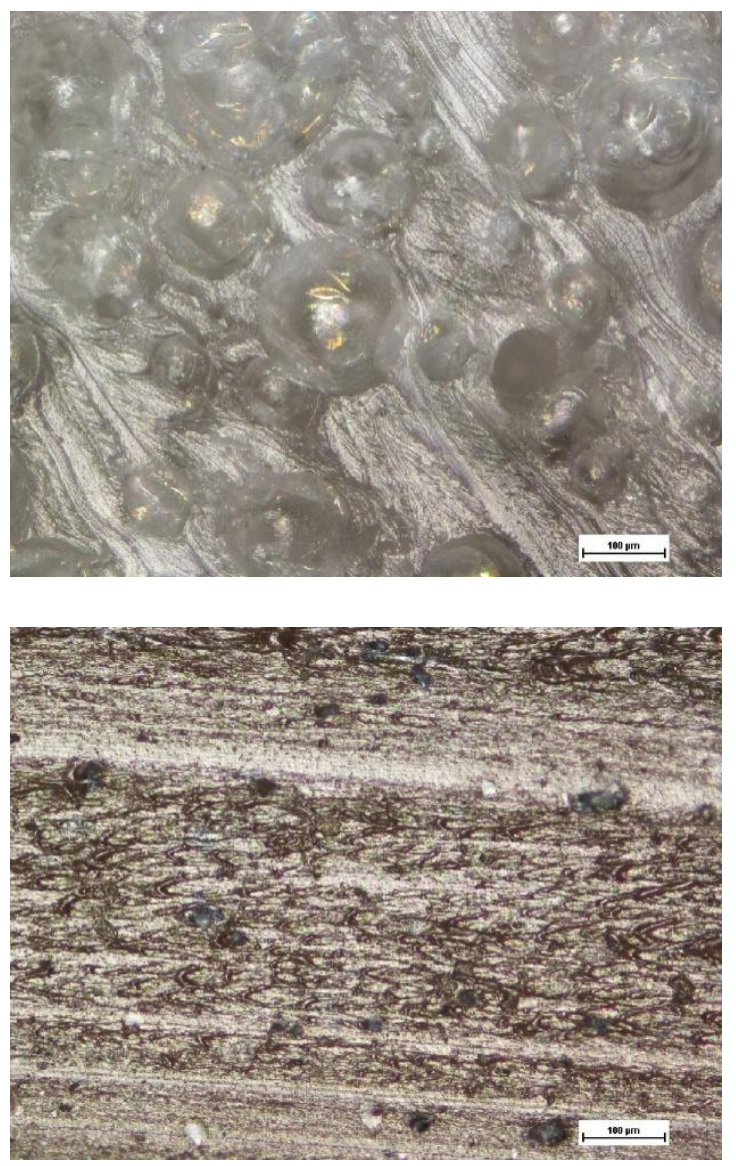

Fig. 8. Fragment of the cross section of the PVC and recycled $P V C$ with $0.5 \%$ microspheres

The difference between the structure of primary PVC and recycled PVC, where a blowing agent was added during the porous processing, is significant. Secondary extruded poly (vinyl chloride) samples have a solid structure with single pores appearing in sizes much smaller than in the case of primary samples. It is noticeable that the number of pores of the secondary samples depends on the amount of blowing agent added during the primary extrusion process. Namely, the smallest number of pores occurs when the blowing agent in the primary extrusion was added in an amount of $0.5 \%$ by mass based on the weight of the processed material, and the largest number of pores occurs when the blowing agent was added in the amount of $2.0 \%$ by weight based on the weight recycled plastic.

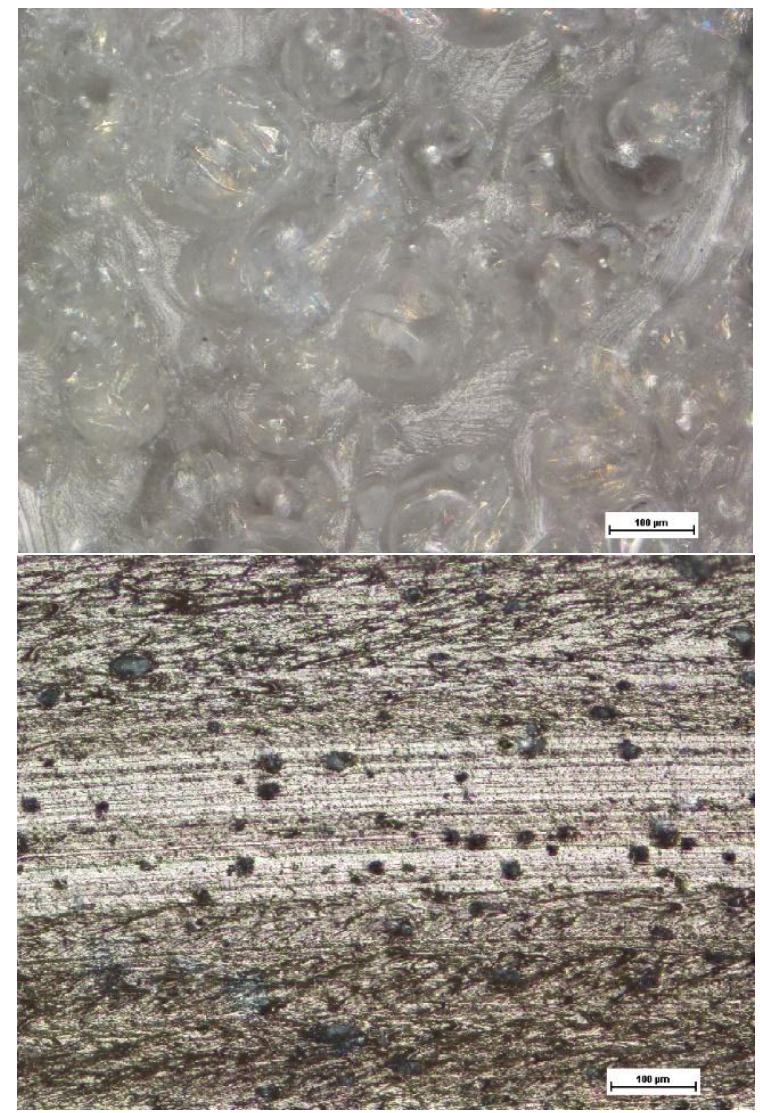

Fig. 9. Fragment of the cross section of the PVC and recycled $P V C$ with $2.0 \%$ microspheres

\section{Conclusions}

Material recycling is a process that involves several stages (segregation, washingand purification, preparation for processing, etc.). Unfortunately, these products lose their mechanical strength and changes occurring in the chemical structure of polymers during their storage (when exposed to atmospheric factors). Appropriate selection of methods and technological lines allows the processing of secondary plasticswith high efficiency and good quality of secondary products. The purpose of secondary plastics processing is to obtain products with repeatable technological properties. This study investigates the impact of the processing process on the properties of secondary materials. After testing for selected strength indicators, it results that in the case of PVC without the content of blowing agent, its value significantly decreases, for secondary plastics, compared to primary plastics. 


\section{T. Garbacz, L. Dulebova}

The porous structure is an advantage of plastics parts produced in the cellular processing, as it results in a decreased amount of the polymeric composite needed in their production. Owing to the use of chemical blowing agents, porous parts have, among others, lower weight, enhanced damping properties, and lower processing shrinkage. The cellularity determines the gaseous phase content in a cellular product, determining at the same time the density decrease value of this product. Such content of the blowing agent in the polymer determines both the coating continuity over the whole cross section and the uniform distribution of pores and their similar sizes.

\section{Acknowledgments}

This work was supported by the National Scholarship Programme of the SlovakRepublic for the Support of Mobility of Students, PhD Students, University Teachers, Researchers and Artists.

\section{References}

1. Kelvin T. Okamoto. (2003) Microcellular processing. Hanser Publishers, Munich, Germany.

2. Gomes Estima M. M. (2004) A bone tissue engineering strategy based on starch scaffolds and bone marrow cells cultured In a flow perfusion bioreactor. Universidade do Minho, Grupo 3B.

3. Garbacz T. (2004) Effect of selected auxiliary agents on the properties of the surface layer of extruded polyethylene. International Polymer Science and Technology pp. 31-36.

4. Garbacz T., Tor A (2007) Effect of porophor content on the useful properties of external composites of compositess obtained by foaming extrusion. Polimery, 52, pp. 286-293.

5. Guo M. C., Heuzey M. C., Carreau P. J. (2007). Cell structure and dynamic properties of injection molded polypropylene foams. Polymer Engineering and Science 47, pp. 1070-1081.
6. Palutkiewicz P., Postawa P. (2016). The investigation of selected properties of the porous moulded parts from talc-filled PP composites. Journal of Cellular Plastics 52, 4, pp. 399-418.

7. Garbacz T. (2011) Properties of triple-layered PVC composites synthesized in the micropore coextrusion method. Polimery, 56, pp. 129-134.

8. Garbacz T., Dulebova L. (2013) Porophors during the extrusion process. Chemistry and Chemical Technology, 7, pp. 113-118.

9. Garbacz T., Dulebova L., Krasinsky V. (2013) Effectiveness of cellular injection molding process. Advances in Science and Technology ,8, 18, pp. 74-80.

10. Rachtanapun P., Selke S.E.M., Matuana L.M. (2003) Microcellular foam of polymer blends of HDPE/PP and their composites with wood fiber. Journal of Applied Polymer Science, 88, pp. 2842-2850.

11. Tejeda E. H., Sahagún C. Z., González-Núñez R., Rodrigue D. (2005) Morphology and mechanical properties of foamed polyethylene-polypropylene blends. Journal of Cellular Plastics, 41, pp. 417-435.

12. Garbacz T., Krasinskyy V. (2012) Title evaluate the effectivesness of the extrusion process. Progresivne Strojarske Technologie a Materialy. PROTECH-MA 2012, Košice, Slovakia, 25.06-27.06. 2012.

13. Tor-Świątek A., Samujło B. (2013) Use of thermovision research to analyze the thermal stability of microcellular extrusion process of poly(vinyl chloride). Maintenance and Reliability, 15, pp. 58-61.

14. Martial S., Jacques F., Audrey C., Clémence N., Rodier E. (2011). New challenges in polymer foaming: A review of extrusion processes assisted by supercritical carbon dioxide, Progress in Polymer Science, 36, pp. 749-766.

15. Urbanczyk L., Alexandre M., Detrembleur Ch. (2010). Extrusion foaming of poly(styrene-coacrylonitrile)/Clay nanocomposites using supercritical $\mathrm{CO}_{2}$, Macromolecural Material Engenering, 295, pp. 915-922.

16. Tor-Swiatek A. (2013). Evaluation of the efectiveness of the microcellular extrusion process of low density polyethylene. Maintenance and Reliability 15, 3, pp. 225-229.

\footnotetext{
Т. Гарбач ${ }^{1}$, Л. Дулебова ${ }^{2}$

${ }^{1}$ Люблінська політехніка, кафедра переробки полімерів,Люблін, Польща

${ }^{2}$ Технічний університет Кошице, кафедра технології і матеріалів, Кошице, Словаччина

t.garbacz@pollub.pl

АНАЛІЗ ВИБРАНИХ ВЛАСТИВОСТЕЙ ЕКСТРУДОВАНОЇ ВТОРИННОЇ СИРОВИНИ
}

Метою дослідження є аналіз фізичних властивостей та морфології вторинної полімерної сировини. Досліджено фізико-механічні властивості зразків первинного та вторинного полівінілхлориду (ПВХ), зокрема міцності під час розтягування, відносного видовження, ударної міцності та твердості. Також досліджено усадку отриманих зразків та їх структуру. Зразки композицій з вторинної сировини одержували методами екструзії та пресування. Встановлено вплив вмісту пороутворювача на показник текучості розплаву та мікро- і макроструктуру одержаних матеріалів.

Ключові слова: ПВХ, пороутворювач, перероблення зі спінюванням, вторинна сировина, властивості, структура. 